\title{
Knowledge and practice regarding prevention of COVID-19 among the Saudi Arabian population
}

\author{
Ammar Ahmed Siddiqui ${ }^{\mathrm{a}, *}$, Freah Alshammary ${ }^{\mathrm{a}}$, Junaid Amin ${ }^{\mathrm{b}}$, Hassaan Anwer Rathore ${ }^{\mathrm{c}}$, \\ Ibne Hassan $^{\mathrm{d}}$, Muhammad Ilyas ${ }^{\mathrm{d}}$ and Mohammad Khursheed Alam ${ }^{\mathrm{e}}$ \\ ${ }^{a}$ Department of Preventive Dental Sciences, College of Dentistry, University of Hai'l, Saudi Arabia \\ ${ }^{\mathrm{b}}$ Department of Physiotherapy, College of Applied Medical Sciences, University of Hai'l, Saudi Arabia \\ ${ }^{\mathrm{c}}$ College of Pharmacy, University of Hai'l, Saudi Arabia \\ ${ }^{\mathrm{d}}$ Department of Management \& MIS, College of Business Administration, University of Hai'l, Saudi Arabia \\ ${ }^{\mathrm{e}}$ Department of Preventive Dental Sciences, College of Dentistry, Jouf University, Saudi Arabia
}

Received 4 April 2020

Accepted 23 June 2020

\begin{abstract}
.
BACKGROUND: Prevention is the best way to manage a pandemic like COVID-19. The World Health Organization has issued public advice to create awareness by providing people knowledge to prevent/protect them from COVID-19. Hence, the present study was planned to assess knowledge of prevention and its practical use amongst samples from the Saudi Arabian population. It can be used to bring awareness among the masses not only in expanding their knowledge about COVID-19 but also on how to enforce a practicing behavior in relation to the prevention of COVID-19. The study is among the pioneer studies on the issue related to knowledge and practice of the prevention of COVID-19 among Saudis and foreign nationals residing in Saudi Arabia.

OBJECTIVE: The prime objective of this study is to examine the existence of knowledge among the Saudi and non-Saudi nationals about COVID-19 and its impact on their behavior to practice the protocols to prevent the disastrous infection of COVID-19. This study has also examined how the residents in Saudi Arabia react to the methods and protection measures adopted by the government for their dominions to eradicate the spread of COVID-19.

METHODS: The study used a survey-based methodology and data was collected from Saudi nationals as well as expatriates living and working in five different regions of Saudi Arabia. Non-probability snowball sampling was used to reach and select the population of the current study. A self-designed, structured, and validated questionnaire was electronically distributed among the respondents. SPSS version 21 was used to analyze the data of the current study.

RESULTS: Out of the 443 respondents, 356 respondents (84\%) knew they had to wash their hands for 20 seconds and did this as well, 303 respondents (75\%) knew that sneezing or coughing into the arm/elbow can prevent the spread of COVID-19 and were doing this as well, 357 respondents (82\%) knew that COVID-19 can be transferred by shaking hands and avoided this, 333 respondents (79\%) knew that they had to maintain a safe distance of at least one meter and kept this distance, 315 respondents (76\%) knew that touching one's face can transfer the virus and avoid this, and 414 respondents (95\%) knew that staying at home can decrease the chances of getting infected. The relationship between different regions and most of the knowledge-based and practice-based questions was significant $(p<0.05)$.
\end{abstract}

*Address for correspondence: Dr. Ammar A. Siddiqui, BDS, MDPH, DDPHRCS Eng., FRSPH UK, Assistant Professor of Dental Public Health, College of Dentistry, University of Hai'l,
Saudi Arabia. Tel.: +966553226295; E-mail: ammarqta2002@ hotmail.com. 
CONCLUSION: Results reveal that there is a significant relationship between knowledge and practice, but the strength of association is weak. It was found that knowledge and practice of COVID-19 was followed differently in the five regions of Saudi Arabia and the level of education of the respondents influenced their choice of practice to protect themselves from the effects of COVID-19. The study has contributed in the body of literature by examining the inter-relationship between knowledge and practice and their use in prevention of COVID-19 among the Saudi population.

Keywords: Awareness, attitude, coronavirus, hygiene practice, infectious diseases, pandemic, COVID-19

\section{Introduction}

Historically, the researched human coronaviruses (HCoVs) are a well-known cause of the "common cold" in almost all parts of the globe. The discoveries of two severe pathogenic HCoVs during the 21st century made them gain more importance because of their virulence. The reason of the deadly outbreaks of HCoVs were the severe acute respiratory syndrome coronavirus (SARS-CoV) and Middle East respiratory syndrome coronavirus (MERS-CoV). The infection was zoonotic, and it became an epidemic by reaching humans through animal reservoirs [1]. In December 2019, suspicious cases of pneumonia were reported in the Chinese city of Wuhan. The cause for this illness was reported to be a novel coronavirus. The infection was later termed COVID-19. Soon after, the infection was declared a pandemic by the World Health Organization (WHO) and became a medical emergency globally $[2,3]$. The common symptoms associated with infection of coronaviruses include fever, dry or productive cough, shortness of breath in severe cases, as well as watery diarrhea [4]. Symptoms of COVID-19 are no different.

In general, 20\%-30\% patients affected by the novel coronavirus require mechanical ventilation. Most of the patients show mild, or at times, no symptoms. However, approximately $10 \%$ mortality has been reported [2]. The chances of deaths are more noticeable in old people, or in immunocompromised patients. As it is a communicable disease, having high rates of transmission, the best measure to control this virulent infection is by preventing it. In the case of COVID-19, we have seen the policy of swift prevention by the Chinese government to control the spread. They imposed a lockdown at the end of January 2020 in the city of Wuhan alongside its neighboring cities. Numerous New Year events and other mass social gatherings were cancelled. Various ports of transportation, such as airports, bus and train stations, were closed down. Besides this, to mitigate the spread, various cities were quarantined $[5,6]$. To flatten the curve of infection spread, alongside preventive measures, monitoring the trend of infection is of prime importance to avoid consequences associated with an epidemic threat. What is happening at the moment will better serve to what needs to be done [7]. To avoid the spread of infection, the Saudi government took remarkable measures at all levels. It is worth mentioning that Saudi Arabia has a population of 33 million, out of which more than $30 \%$ are non-national residents. Beside that millions of Umrah, and Hajj pilgrims visit the Kingdom for religious rituals from all over the world. They usually stay for an average of 10 days and social distancing is nearly impossible in this case. Nearly half of the pilgrims are above 50 years of age and have already existing chronic diseases. Among these pilgrims, $40-90 \%$ report respiratory illnesses $[8,9]$. Considering these statistics, and the medical emergencies caused by COVID-19 around the globe, Saudi Arabia becomes more vulnerable to cross-border infections travelling into the country. In this context, various preventive measures taken by the Saudi government such as timely suspension of pilgrimage, partial lockdown in various cities, propagating the use of disinfecting agents, and a campaign by the Ministry of Health created an awareness program regarding the prevention of COVID- 19 which is highly appreciable. Knowing the best treatment to be protected against COVID-19 is by preventing it, the present study was planned to measure the general public knowledge, and practice towards prevention protocols of COVID-19. To the best of our knowledge, this is the first study of its kind in the country. Although the present findings are not generalizable to the whole Saudi Arabian population, it can still be taken as a baseline for future studies with more representative samples from each region.

\section{Material and methods}

This was a survey-based descriptive study which recorded responses from all five regions of Saudi Arabia used the nonprobability snowball sampling 
technique. A self-made face and content validated questionnaire was developed based on WHO advice for the public regarding the prevention of COVID-19 [10]. The WHO advises to stay home as much as possible, keep social distance, wash hands with soap and water for 20 seconds, cover mouth when coughing, and call the local medical emergency number with suspected symptoms. The questionnaire consisted of three parts. The first part contained information regarding sociodemographic characteristics such as sex, nationality, age, education level, and region of residence. The second part contained 12 questions, six each for knowledge, and its practice. The questions included in this section were on hand hygiene practice, coughing, maintaining social distance, and modes of virus transfer. The third part also contained six separate questions of protection against COVID-19 as advised by the WHO. These questions captured respondents' knowledge regarding quarantine for two weeks, calling 937, an emergency health helpline number, in case of emergency or advice, information regarding virus symptoms, and spread. All the responses were recorded as yes or no. Ethical approval was obtained through the Research Ethical Approval Committee of the University of Hai'l with approval number H-2020-076. Information was gathered from respondents electronically after informed consent. The objective of the study was explained to the respondents prior to the consent and the participation was entirely voluntary. A total of 443 responses were recorded. Data was collected from 20th March 2020 until 1st April 2020. All the data was coded and transferred to Microsoft Excel, and then transferred to Statistical Package for Social Sciences (SPSS) version 21 for analysis. Data was displayed as number, percentages and graph. Pearson chi-square test was used to check the statistical significance. $P$ value $<0.05$ was considered significant. For related categorical variables of knowledge and practice McNemar test was used. Phi coefficient was employed to further check the strength of association between two dichotomous variables.

\section{Results}

Out of 443 respondents, $238(53.7 \%)$ were male respondents and 205 (46.3\%) were female respondents. A vast majority of respondents were Saudi citizens, $317(71.6 \%)$, as compared to non-Saudi residents, $126(28.4 \%)$. The majority of the respondents, 331 (74.7\%), were university graduated and the
Table 1

Demographic Characteristics of Respondents $(n=443)$

\begin{tabular}{lc}
\hline Demographic characteristics & Number of respondents $(\%)$ \\
\hline Gender & $238(53.7)$ \\
Male & $205(46.3)$ \\
Female & \\
Age in Years & $191(43.1)$ \\
$18-32$ & $176(39.7)$ \\
$33-49$ & $59(13.3)$ \\
$50-59$ & $17(3.8)$ \\
60 and above & \\
Nationality & $317(71.6)$ \\
Saudi & $126(28.4)$ \\
Non Saudi & \\
Level of Education & $10(2.3)$ \\
Primary & $102(23.0)$ \\
Secondary & $331(74.7)$ \\
University Education & \\
Region & $199(44.9)$ \\
Northern & $29(6.5)$ \\
Southern & $30(6.8)$ \\
South-West & $71(16.0)$ \\
Eastern & $114(25.7)$ \\
Central &
\end{tabular}

lowest proportion, 10 (2.3\%), had primary education. The highest response rate was from the Northern region, 199 (44.9\%), followed by the central region, 114 (25.7\%), and the Eastern region, 71 (16.0\%), while the lowest response rate was from the Southern region, $29(6.5 \%)$. The demographic characteristics of the respondents are depicted in Table 1.

Among all the 443 respondents, 425 respondents (96\%) knew they had to was their hands with soap and water for 20 seconds, however 69 respondents $(16.2 \%)$ were not practicing this knowledge. A small number of respondents, 18 (4\%), were ignorant of washing hands for 20 seconds while out of these four were ignorant though doing the practice. Responding to Q3 (sneezing or coughing into your arm/elbow can prevent spreading of corona virus), 405 respondents $(91 \%)$ were found knowledgeable, of which $102(25 \%)$ were not practicing it. Thirty-eight respondents (9\%) were lacking the knowledge about Q3, of which eight were doing the practice. In response to Q5 (do you know that COVID-19 can be transferred by shaking hands?), 435 respondents (98\%) had knowledge, 357 respondents $(82 \%)$ were practicing the knowledge, while 78 respondents (18\%) had knowledge but were not practicing it. Only eight respondents were ignorant about $\mathrm{Q} 5$, of which three respondents were doing the practice.

In response to Q7 (do you know that you should maintain a safe distance of at least one meter while sitting with other people to protect yourself from COVID-19?), overall 423 respondents (95\%) had 
Table 2

Knowledge-based vs. Practice-based Variables $(n=443)$

\begin{tabular}{|c|c|c|c|c|c|}
\hline Knowledge variables & & & Practice V & & \\
\hline $\begin{array}{l}\text { Q1. Do you know that washing your } \\
\text { hands for } 20 \text { seconds can prevent the } \\
\text { virus? }\end{array}$ & $\begin{array}{l}\text { Q2. Do yo } \\
\text { Yes n }(\%) \\
\text { No n }(\%) \\
\text { Total n }(\%) \\
\end{array}$ & $\begin{array}{l}\text { hands for } \\
\text { Yes } n(\%) \\
356(84) \\
4(21.9) \\
360(81)\end{array}$ & $\begin{array}{l}\text { onds? } \\
\text { No n }(\%) \\
69(16) \\
14(78.1) \\
83(19) \\
\end{array}$ & $\begin{array}{l}\text { Total n }(\%) \\
425(96) \\
18(4) \\
443(100) \\
\end{array}$ & $\begin{array}{c}P \text { value } \\
0.000^{*}\end{array}$ \\
\hline $\begin{array}{l}\text { Q3. Do you know that sneezing or } \\
\text { coughing into your arm/elbow can } \\
\text { prevent the spread of the virus? }\end{array}$ & $\begin{array}{l}\text { Q4. Do yo } \\
\text { Yes n }(\%) \\
\text { No n }(\%) \\
\text { Total n }(\%) \\
\end{array}$ & $\begin{array}{l}\text { ze into youl } \\
\text { Yes } \mathrm{n}(\%) \\
303(75) \\
8(20.8) \\
311(70.2)\end{array}$ & $\begin{array}{l}\text { elbow? } \\
\text { No n }(\%) \\
102(25) \\
30(79.2) \\
132(29.8) \\
\end{array}$ & $\begin{array}{c}\text { Total n }(\%) \\
405(91) \\
38(9) \\
443(100) \\
\end{array}$ & $\begin{array}{c}P \text { value } \\
0.000^{*}\end{array}$ \\
\hline $\begin{array}{l}\text { Q5. Do you know that the virus can } \\
\text { be transferred by shaking hands? }\end{array}$ & $\begin{array}{l}\text { Q6. Do yo } \\
\text { Yes n }(\%) \\
\text { No n }(\%) \\
\text { Total n }(\%) \\
\end{array}$ & $\begin{array}{l}\mathrm{d} \text { shaking h } \\
\text { Yes } \mathrm{n}(\%) \\
357(82) \\
3(38) \\
360(81)\end{array}$ & $\begin{array}{l}\text { whilst greetil } \\
\text { No } \mathrm{n}(\%) \\
78(18) \\
5(63) \\
83(19)\end{array}$ & $\begin{array}{l}\text { Total n }(\%) \\
435(98) \\
8(2) \\
443(100) \\
\end{array}$ & $\begin{array}{c}P \text { value } \\
0.000^{*}\end{array}$ \\
\hline $\begin{array}{l}\text { Q7. Do you know that you should } \\
\text { maintain a safe distance of at least } \\
\text { one meter whilst sitting with other } \\
\text { people to protect yourself from the } \\
\text { virus? }\end{array}$ & $\begin{array}{l}\text { Q8. Do yo } \\
\text { meeting ot } \\
\text { Yes n (\%) } \\
\text { No n (\%) } \\
\text { Total n (\%) }\end{array}$ & $\begin{array}{c}\text { tain a dista } \\
\text { or protectior } \\
\text { Yes n (\%) } \\
333(79) \\
5(25) \\
338(76)\end{array}$ & $\begin{array}{c}\text { at least one } \\
\text { nst the virus } \\
\text { No n (\%) } \\
90(21) \\
15(75) \\
105(24) \\
\end{array}$ & $\begin{array}{l}\text { whilst } \\
\text { Total n (\%) } \\
423(95) \\
20(5) \\
443(100) \\
\end{array}$ & $\begin{array}{l}P \text { value } \\
0.000^{*}\end{array}$ \\
\hline $\begin{array}{l}\text { Q9. Do you know that touching your } \\
\text { face can transfer the virus? }\end{array}$ & $\begin{array}{l}\text { Q10. Do y } \\
\text { Yes n }(\%) \\
\text { Non }(\%) \\
\text { Total n }(\%) \\
\end{array}$ & $\begin{array}{l}\text { id touching } \\
\text { Yes } \mathrm{n}(\%) \\
315(76) \\
6(22) \\
321(72) \\
\end{array}$ & $\begin{array}{l}\text { face? } \\
\text { No n }(\%) \\
101(24) \\
21(78) \\
122(28) \\
\end{array}$ & $\begin{array}{l}\text { Total n }(\%) \\
416(94) \\
27(6) \\
443(100) \\
\end{array}$ & $\begin{array}{c}P \text { value } \\
.000^{*}\end{array}$ \\
\hline $\begin{array}{l}\text { Q11. Do you know that staying at } \\
\text { home can decrease the chances of } \\
\text { getting infected? }\end{array}$ & $\begin{array}{l}\text { Q12. Do y } \\
\text { Yes n (\%) } \\
\text { No n (\%) } \\
\text { Total n (\%) }\end{array}$ & $\begin{array}{l}\text { at home q } \\
\text { Yes n }(\%) \\
414(95) \\
7(78) \\
421(95)\end{array}$ & $\begin{array}{l}\text { ften? } \\
\text { No n (\%) } \\
20(5) \\
2(22) \\
22(5)\end{array}$ & $\begin{array}{l}\text { Total n }(\%) \\
434(98) \\
9(2) \\
443(100)\end{array}$ & $\begin{array}{c}P \text { value } \\
0.019^{*}\end{array}$ \\
\hline
\end{tabular}

${ }^{*} p$ value obtained from Mc Nemar-Bowker Test.

the knowledge, while 333 respondents (79\%) were practicing the knowledge, whereas 90 respondents (21.2\%) were aware but were not practicing it. Twenty respondents $(5 \%)$ did not have knowledge about Q7, of which five were practicing maintaining a distance of at least one meter whilst meeting others as a measure of protection against COVID-19.

Regarding Q9 (do you know that touching your face can transfer COVID-19?), overall 416 respondents (94\%) had knowledge, 315 respondents (76\%) showed knowledge and practiced it, whereas 101 respondents (24\%) were not practicing it despite having the knowledge. Likewise, six respondents $(22 \%)$ were doing the practice even though they did not have the knowledge that touching their faces can transfer the virus. Out of the total 122 respondents that were not practicing the knowledge, $21(17 \%)$ did not have the knowledge.

In response to Q11 (do you know that staying at home can decrease the chances of getting infected?), the majority of the respondents, 414 (95\%), had knowledge and were practicing it as well, but 20 respondents $(5 \%)$ were not practicing it even when they had the knowledge. Only two respondents (22\%) were found without knowledge and practice, while seven were staying at home quite often despite the lack of knowledge. Table 2, Figs. 1 and 2 categorize the responses of knowledge-based and practice-based questions.

The measurement of strength of association amongst two binary dichotomous variables (Knowledge and Practice) was checked by Phi coefficient of association. Although we had already rejected our null hypothesis, which states that there is no difference to preventive knowledge for practice, the strength of association is nevertheless listed in Table 3. It was found that there is a very weak to weak correlation of knowledge and practical use. The relationships between related variables of knowledge and prevention of COVID-19 amongst the Saudi 


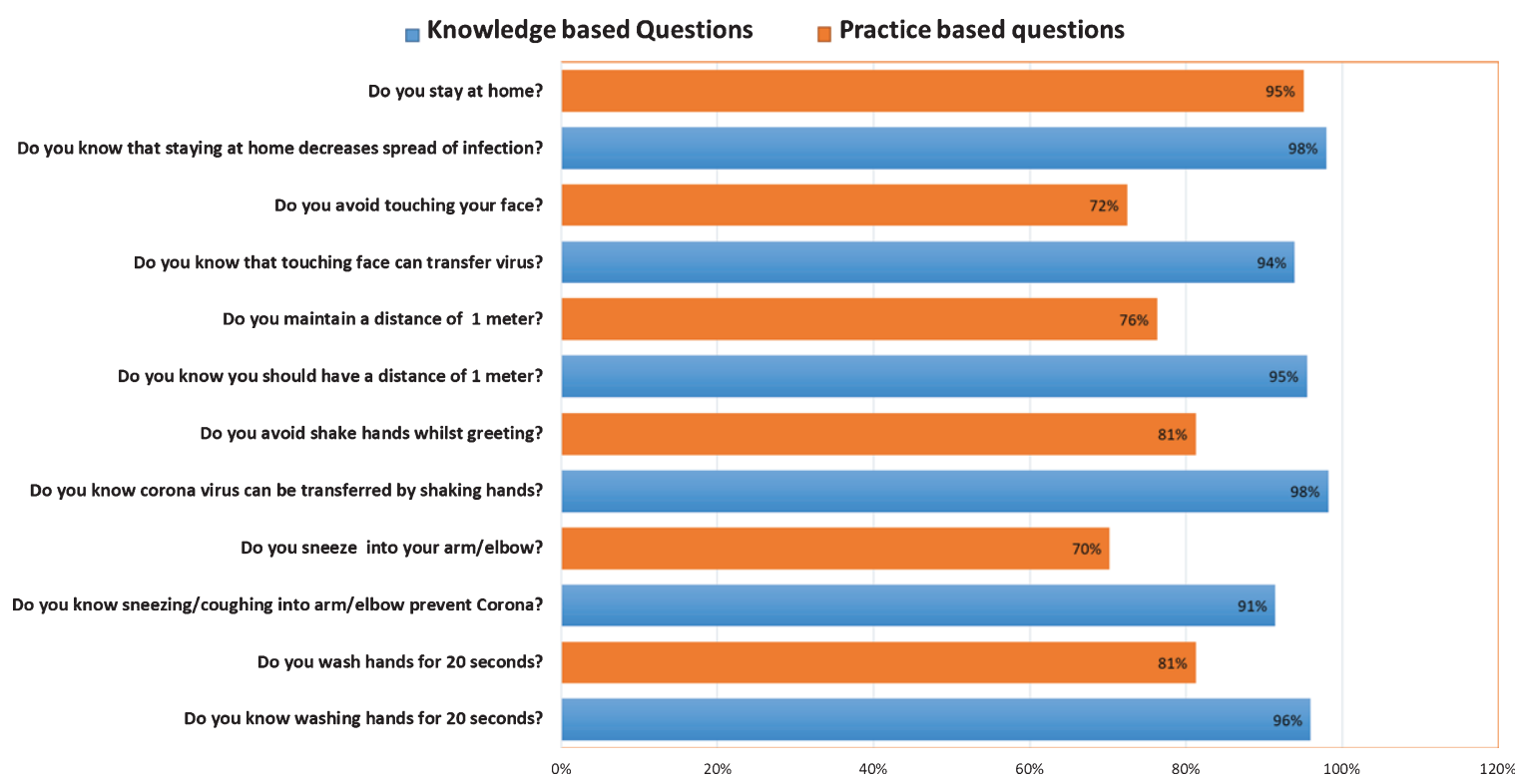

Fig. 1. Relationship between knowledge- and practice-based questions.

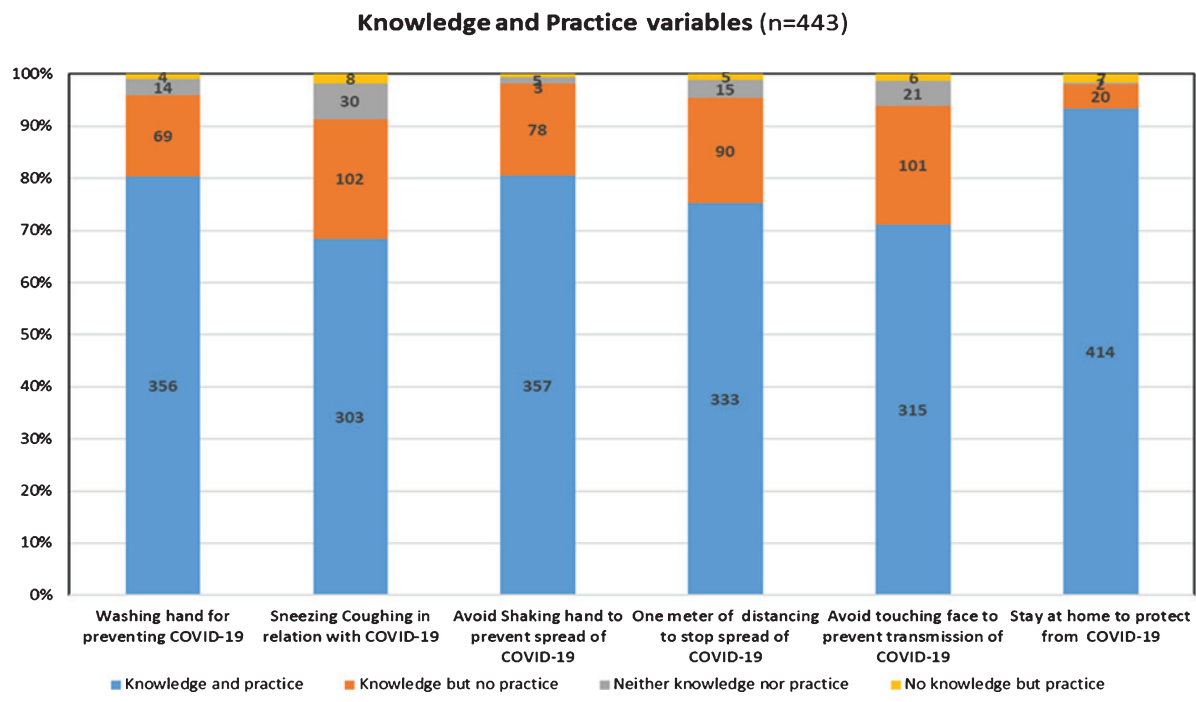

Fig. 2. Relationship of knowledge and practice of COVID-19 among the Saudi Arabian population.

population is strongly associated (Table 2) but weakly correlated (Table 3 ).

The relationship between region and knowledgebased Q1 (do you know that washing your hands for 20 seconds can help prevent against COVID-19?) was performed and it was found that the relationship between these variables was significant: $X^{2}(4$, $n=443)=, 26.875 p=0.00$. However, there was no significant difference $(p>0.05)$ in terms of education, age, nationality, and gender with Q1. Likewise, the relationship between region and majority of the knowledge-based questions was found significant $(p<0.05)$.

Moreover, the relationship between level of education and Q2 (do you know that sneezing or coughing into your arm/elbow can prevent the spread of COVID-19?) was significant: $\mathrm{X}^{2}(2, n=443)=$, $11.250 p=0.04$. But there was no significant difference $(p>0.05)$ in terms of age, nationality, region, and gender with Q2. Similarly, the relationship between education and most of the knowledge-based questions was also significant $(p<0.05)$. 
Table 3

Measurement of Strength of Association

\begin{tabular}{lcc}
\hline Variable & Phi Coefficient & Interpretation \\
\hline 1. Influence of knowledge of washing hands on practice & 0.31 \\
2. Influence of knowledge of sneezing/coughing on practice & 0.33 \\
3. Influence of knowledge of not shaking hands on practice & 0.15 \\
4. Influence of knowledge of social distance on practice & Weak & 0.26 \\
5. Influence of knowledge of spreading of infection by touching face on practice & Very weak & Very weak \\
6. Influence of knowledge of staying at home to prevent infection on practice & Very weak & 0.11 \\
\hline
\end{tabular}

Table 4

Relationship between Demographic Variables and Knowledge-based Questions

\begin{tabular}{|c|c|c|c|c|c|}
\hline Knowledge-based Questions & Age & Gender & $\begin{array}{c}\text { Level of } \\
\text { Education }\end{array}$ & Nationality & $\overline{\text { Region }}$ \\
\hline $\begin{array}{l}\text { 1. Do you know that washing your hands for } 20 \text { seconds can help you prevent } \\
\text { against the virus? }\end{array}$ & n.s & n.s & n.s & n.s & $000^{*}$ \\
\hline $\begin{array}{l}\text { 2. Do you know that sneezing or coughing into your arm/elbow can prevent } \\
\text { the spread of the virus? }\end{array}$ & n.s & n.s & $0.004^{*}$ & n.s & n.s \\
\hline 3. Do you know that the virus can be transferred by shaking hands? & n.s & n.s & n.s & n.s & $006^{*}$ \\
\hline $\begin{array}{l}\text { 4. Do you know that you should maintain a safe distance of at least one meter } \\
\text { while sitting with other people to protect yourself from the virus? }\end{array}$ & n.s & n.s & $0.051^{*}$ & n.s & $0.000^{*}$ \\
\hline 5. Do you know that touching your face can transfer the virus? & n.s & n.s & $0.000^{*}$ & n.s & $0.000^{*}$ \\
\hline $\begin{array}{l}\text { 6. Do you know that staying at home can decrease the chances of getting } \\
\text { infected? }\end{array}$ & n.s & n.s & n.s & n.s & $0.000^{*}$ \\
\hline 7. Do you know that you can call 937 to seek medical attention for the virus? & n.s & $0.050^{*}$ & n.s & $0.000^{*}$ & $0.006^{*}$ \\
\hline 8. Do you know that older people are at higher risk of developing the virus? & n.s & n.s & n.s & n.s & $0.009^{*}$ \\
\hline 9. Do you know that the virus can stay on objects for a few days to weeks? & n.s & n.s & $0.035^{*}$ & n.s & $0.002^{*}$ \\
\hline $\begin{array}{l}\text { 11. Do you know that you should avoid meeting people if you have a cough or } \\
\text { high temperature? }\end{array}$ & n.s & n.s & $0.009^{*}$ & n.s & $0.001^{*}$ \\
\hline $\begin{array}{l}\text { 12. Do you know that you should seek medical care if you have a cough, } \\
\text { higher temperature, and have difficulty breathing? }\end{array}$ & n.s & n.s & $0.026^{*}$ & n.s & $0.000^{*}$ \\
\hline
\end{tabular}

n.s shows non-significant. ${ }^{*} p$ value obtained from $\chi^{2}$ test.

Furthermore, concerning gender, a significant relationship was established for Q7 (do you know that you can call 937 to seek medical attention for COVID19?) and Q10 (do you know that people who have travelled from abroad should not meet other people for two weeks?) with values of X2 $(1, n=443)=$, $3.834 p=0.050$, and $\mathrm{X} 2(1, n=443)=, 4.977 p=0.026$ respectively.

With regards to age, a significant relationship was not established with the aforementioned knowledgebased questions $(p<0.05)$. The relationship between demographic variables and knowledge-based questions is depicted in Table 4.

The relationship between region and practicebased Q1 (do you wash your hands for 20 seconds?) was performed, and it was found that the relationship between these variables was significant: $\mathrm{X}^{2}(4$, $n=443)=, 22.426 p=0.00$. Likewise, the relationship between region and all of the practice-based questions was significant $(p<0.05)$.

Moreover, the relationship between education and Q1 was significant: X2 $(2, n=443)=, 6.712 p=0.035$.
Similarly, the relationship between level of education, Q2 (do you sneeze into your arm/elbow?) and Q5 (do you avoid touching your face?) was also significant $(p<0.05)$.

A significant relationship was established between age and practice-based Q3 (do you avoid shaking hands whilst greeting?) and Q4 (do you maintain a distance of at least one meter?), with values of X2 (3, $n=443)=, 13.054 p=0.005$ and $(3, n=443)=, 15.443$ $p=0.001$ respectively.

There was no significant relationship between gender and the aforementioned practice-based questions $(p<0.05)$. The relationship between demographic variables and practice-based questions is depicted in Table 5.

\section{Discussion}

The current study sought to evaluate the knowledge and practice of preventive measures recommended by the WHO to prevent COVD-19 among the 
Table 5

Relationship between Demographic Variables and Practice-based Questions

\begin{tabular}{|c|c|c|c|c|c|}
\hline Practice-based questions & $\begin{array}{c}\text { Age } \\
p \text {-value }\end{array}$ & $\begin{array}{l}\text { Gender } \\
p \text {-value }\end{array}$ & $\begin{array}{c}\text { Level of } \\
\text { education } \\
p \text {-value }\end{array}$ & $\begin{array}{c}\text { Nationality } \\
p \text {-value }\end{array}$ & $\begin{array}{l}\text { Region } \\
p \text {-value }\end{array}$ \\
\hline 1. Do you wash your hands for 20 seconds? & n.s & n.s & $0.035^{*}$ & $0.046^{*}$ & $0.000^{*}$ \\
\hline 2. Do you sneeze into your arm/elbow? & n.s & n.s & $0.001^{*}$ & n.s & $0.000^{*}$ \\
\hline 3. Do you avoid shaking hands whilst greeting? & $0.005^{*}$ & n.s & n.s & n.s & $0.000^{*}$ \\
\hline $\begin{array}{l}\text { 4. Do you maintain a distance of at least one meter whilst meeting others for } \\
\text { protection against the virus? }\end{array}$ & $0.001^{*}$ & n.s & n.s & n.s & $0.000^{*}$ \\
\hline 5. Do you avoid touching your face? & n.s & n.s & $0.002^{*}$ & n.s & $030^{*}$ \\
\hline 6. Do you stay at home quite often? & n.s & n.s & n.s & n.s & $0.011^{*}$ \\
\hline
\end{tabular}

n.s shows non-significant. ${ }^{*} p$ value obtained from $\chi^{2}$ test.

general population in Saudi Arabia. At the start of the COVID-19 outbreak, early transmissions were reported from animal to human [11], whereas at a later stage all transmissions that constituted the pandemic in more than 180 countries were from human to human. To date, the evidence of effective treatment against this deadly disease has not been reported, thus the main intervention is supportive and focuses on the prevention of its transmission [12]. In this regard, it is imperative to follow the guidelines set by the WHO to prevent the transmission from human to human. This is the second serious outbreak in Saudi Arabia in less than ten years following MERS-CoV in 2012 [13]. Globally, costs of this outbreak are not limited to health issues but also have significant effects on economic and psychosocial issues. In the same continuum as the economy, Saudi Arabia is not operating in a vacuum and has felt the world economic crisis. The Kingdom has already announced downsizing its 2020 budget by a huge amount of $\$ 13.3$ billion by reiterating their strong commitment that the health budget will be boosted further to fight the pandemic of COVID-19 [14].

Saudi Arabia has exerted all its struggles to combat COVID-19 on a priority basis to ensure the safety of the community and to let the masses feel that their matters of health are in safe hands. The Ministry of Health (MOH) has played a significant part to increase the awareness of the public about the different aspects of the disease including symptoms, spread, and prevention. Right from the start of the outbreak of COVID-19, MOH started a campaign to educate and increase the awareness about COVID-19 of all members of society, which has helped significantly to prevent, and slow down the spread of the virus in the Kingdom. The sources used to disseminate the information were personal mobile messages, advertisements on social media, mobile applications, use of radio and television, teleconsultation through the Mawid App, road signs and electronic screens in public places [15].

The main strength of this study are the participants who have a significant knowledge of the prevention strategies against COVID-19 in all the knowledgebased questions, but the strength of association of practicing the knowledge was weak, although statistically highly significant. The findings of this study also show good hygiene practices among participants to prevent the transmission of the disease.

The respondents' knowledge is incorporated with significant efforts and measures taken by the $\mathrm{MOH}$ to increase awareness of the public about the different aspects of the disease including symptoms, spread, and prevention. More than two billion awareness messages about COVID-19 were sent in 24 languages to residents on their personal mobile phones. These messages predominantly included instructions to prevent the spread, highlighting staying at home, sneezing into the elbow, the importance of washing hands, practicing social distancing, avoiding shaking hands and direct contact with others [16]. These instructions were also part of our study and we found a significant knowledge of the respondents regarding these items as well. A recent study conducted in China to assess the knowledge, attitudes, and practices towards COVID-19 also reported that health education programs were quite helpful to improve the knowledge and practice of the community [17]. Likewise, the study conducted on the SARS-CoV2 outbreak in China reported the same findings [18].

The finding of a high level of knowledge among the Saudi population was not expected as this survey was conducted in the early stage of the outbreak. Similar findings were observed in a previous study conducted in 2017 about the MERS-CoV epidemic in Saudi Arabia [19], and during the SARS outbreak in Hong Kong [20]. This study reported a high level of knowledge and practice among the majority of the participants about COVID-19 prevention. The 
findings of present study are in line with Chinese study on COVID-19 [17], and a Japanese study conducted in 2009 on the H1N1 influenza epidemic [21]. The present study found a significant association between different regions of Saudi Arabia in terms of knowledge and practice. These findings however disagree with a previous study on MERS-CoV conducted in Saudi Arabia [19].

\section{Limitations of the study}

Though the sample has been collected from all major regions of the country, sample sizes from different regions varied, which could be a limitation to the present study. Moreover, the study only focuses on the knowledge of the general population in the initial days of the pandemic (from 20 March to 1 April 2020) and therefore might not be generalizable outside the domain of the defined population and scope of the present study.

\section{Conclusion}

This study has adopted an approach to reach out not only to Saudi nationals but to non-Saudi residents as well, to perceive the impact that it could have in the absence of the knowledge and practice among residents about COVID-19. This study revealed that it is important to have knowledge but imperative to practicing it by exercising different techniques in the wake of a pandemic like COVID-19. It is thus proven that there is a significant relationship between both of them and would help in muting the disastrous effects of this virus on human beings. This study highlighted the impact of government institutes on human beings to help combat the infectious diseases like COVID19 . This study not only appreciates the positive steps in terms of knowledge and practice followed by the Saudi government but also provides a rule of thumb for other regions and countries to follow in fighting against such pandemics. As an under-researched area, this study has pioneered the impact of knowledge and practice in helping to prevent COVID-19 and viral infections among masses.

\section{Acknowledgments}

This project was funded by the Scientific Research Deanship at the University of Hai'l, Saudi Arabia through project number COVID-1903.

\section{Conflict of interest}

None to report.

\section{References}

[1] De Wilde AH, Snijder EJ, Kikkert M, van Hemert MJ. Host factors in coronavirus replication. Curr Top Microbiol Immunol. 2018;419:1-42. doi:10.1007/82_2017_25

[2] Paules CI, Marston HD, Fauci AS. Coronavirus infectionsmore than just the common cold. JAMA. 2020;323:207-8. doi:10.1001/jama.2020.0757

[3] Lu H, Stratton CW, Tang YW. Outbreak of Pneumonia of Unknown Etiology in Wuhan China: the Mystery and the Miracle. J Med Virol. 2020;jmv.25678.

[4] de Wit E, van Doremalen N, Falzarano D, Munster VJ. SARS and MERS: recent insights into emerging coronaviruses. Nat Rev Microbiol. 2016;14(8):523-34. doi:10.10 38/nrmicro.2016.81

[5] Crossley G. Wuhan lockdown 'unprecedented', shows commitment to contain virus: WHO representative in China. Reuters. 2020;Online.

[6] Wu JT, Leung K, Leung GM. Nowcasting and forecasting the potential domestic and international spread of the 2019nCoV outbreak originating in Wuhan, China: a modelling study. Lancet 2020. https://www.sciencedirect.com/science /article/pii/S0140673620302609 (accessed 6 Feb2020).

[7] Al Hasan SM, Saulam J, Kanda K, Hirao T. The novel coronavirus disease (COVID-19) outbreak trends in mainland China: a joinpoint regression analysis of the outbreak data from January 10 to February 11, 2020. [Submitted]. Bull World Health Organ. E-pub: 17 February 2020. doi: http:// dx.doi.org/10.2471/BLT.20.253153

[8] Ebrahim SH, Memish ZA, Uyeki TM, et al. Pandemic H1N1 and the 2009 Hajj. Science. 2009;326:938-40.

[9] Ebrahim SH, Memish ZA. COVID-19: preparing for superspreader potential among Umrah pilgrims to Saudi Arabia. The Lancet. 2020 Feb 27.

[10] Advice for public [Internet]. World Health Organization. World Health Organization; [cited 2020Apr1]. Available from: https://www.who.int/emergencies/diseases/novel-cor onavirus-2019/advice-for-public

[11] Biscayart C, Angeleri P, Lloveras S, Chaves TD, Schlagenhauf P, Rodriguez-Morales AJ. The next big threat to global health? 2019 novel coronavirus (2019-nCoV): What advice can we give to travellers?-Interim recommendations January 2020, from the Latin-American society for Travel Medicine (SLAMVI).

[12] Yang Y, Peng F, Wang R, Guan K, Jiang T, Xu G, Sun J, Chang C. The deadly coronaviruses: The 2003 SARS pandemic and the 2020 novel coronavirus epidemic in China. Journal of Autoimmunity. 2020:102434.

[13] Assiri A, Al-Tawfiq JA, Al-Rabeeah AA, Al-Rabiah FA, Al-Hajjar S, Al-Barrak A, Flemban H, Al-Nassir WN, Balkhy HH, Al-Hakeem RF, Makhdoom HQ. Epidemiological, demographic, and clinical characteristics of 47 cases of Middle East respiratory syndrome coronavirus disease from Saudi Arabia: a descriptive study. The Lancet Infectious Diseases. 2013;13(9):752-61.

[14] Saudi Arabia to cut 2020 budget [Internet]. Anadolu Ajansi. [cited 2020Apr4]. Available from: https://www.aa. com.tr/en/economy/saudi-arabia-to-cut-2020-budget/1771 232 
[15] MOH.Novel Coronavirus (COVID-19) [Internet]. Public Health - Novel Coronavirus (COVID-19). [cited 2020Apr4]. Available from: https://www.moh.gov.sa/en/HealthAware ness/EducationalContent/PublicHealth/Pages/corona.aspx

[16] MoH broadcast over 2bn awareness messages about coronavirus [Internet]. Saudigazette. NEWSPAPER_NAME; 2020 [cited 2020Apr4]. Available from: http://www.saudi gazette.com.sa/article/591444?fbclid=IwAR0wqXciqUoT XSf6hBoHQytqByCvPBDqgPSkLobaXDMuhr3QzFDpIBH7zw

[17] Zhong BL, Luo W, Li HM, Zhang QQ, Liu XG, Li WT, Li Y. Knowledge, attitudes, and practices towards COVID19 among Chinese residents during the rapid rise period of the COVID-19 outbreak: a quick online cross-sectional survey. International Journal of Biological Sciences. 2020; 16(10): 1745.

[18] Chen S, Qiu Z. People groups'responses to sars in the community $[\mathrm{J}]$. Chinese Rural Health Service Administration. $2003 ; 6$.
[19] ALdowyan N, Abdallah AS, El-Gharabawy R. Knowledge, Attitude and Practice (KAP) Study about Middle East Respiratory Syndrome Coronavirus (MERS-CoV) among Population in Saudi Arabia. International Archives of Medicine. 2017;10.

[20] Deng JF, Olowokure B, Kaydos-Daniels SC, Chang HJ, Barwick RS, Lee ML, Deng CY, Factor SH, Chiang CE, Maloney SA, Team TS. Severe acute respiratory syndrome (SARS): Knowledge, attitudes, practices and sources of information among physicians answering a SARS fever hotline service. Public Health. 2006;120(1):15-9.

[21] Morishima M, Kishida K. Understanding attitudes toward hygiene mask use in Japanese daily life by using a repeated cross-sectional survey. Work. 2018;61(2):303-11. 